\title{
How Divergent Were Returns to Education Investments in China?
}

\author{
Jan P Voon (Corresponding author) \\ Associate Prof, Department of Economics, Lingnan University \\ 8 Castle Peak Road, Tuen Mun, Hong Kong \\ Tel: 852-2616-7175Ｅ-mail: jvoon@ln.edu.hk
}

Jan Cham Voon

$\mathrm{PhD}$, Faculty of Education and Languages

Open University, Malaysia

Tel: 852-9076-9068Ｅ-mail: timvoon@hotmail.my

Received: May 26, 2011

doi:10.5539/ass.v8n1p67

\author{
Accepted: July 21, $2011 \quad$ Published: January 1, 2012 \\ URL: http://dx.doi.org/10.5539/ass.v8n1p67
}

\begin{abstract}
This paper uses the wage increment approach to measure the social and private returns to educational investments in China at various educational levels and how they change over time. The social returns to the investments in higher education were found to be increasing over time whilst the returns to the secondary level were declining over time. This indicates that China should raise its annual investment in higher education vis-à-vis secondary schools. We also found that the private returns to undergraduate level were substantially smaller than those to secondary level. This may lead to under-enrollment in undergraduate education. The above divergences or imbalances, if not rectified, could give rise to increasing scale of skilled labor shortages at the time when the economy boomed.
\end{abstract}

Keywords: Returns to education, Wage increment, Costs of schooling, Divergence, China

\section{Introduction}

Social and private benefits from investments in education were often measured using the wage increment approach, which represents the increase in wage earnings of students over what they would have earned without the education (Hertz, 2003; Li, 2003; Voon, 2001, Acemoglu 1996; Johnson and Chow, 1997; Ashenfelter and Krueger, 1994). Using this approach, social rates of return to education were reported in general to be smaller than private rates of return (Zhang et al, 2005; Psacharopoulos, 1994; Polachek and Siebert, 1993). The rates of return were always found to be smallest at the highest educational level. In the case of China, the rates of returns to education were found to be increasing over time ( $\mathrm{Li}$ et al, 2005).

This paper also uses the wage increment approach. We assess the size of benefits accruable to China from its investments in education at various levels (from secondary to postgraduate) and over time. A large effort has already been devoted to analyzing educational returns in China. But the focuses of past empirical research are quite different. For instance, $\mathrm{Li}$ (2003) examined how China's economic transition or reform affects its returns to education. Brown and Park (2002) examined the effects of individual, family and school characteristics on China's educational attainment, focusing in particular on the importance of poverty and school quality. Gustafsson and $\mathrm{Li}$ (2000) focused on the gender earnings gap in urban China. Zhao (2001) looked at the earning differentials between state and non-state enterprises in urban China. Fleisher and Wang (2004) investigated how skill differentials and market segmentation affect return to schooling (for example, they attribute low private returns to schooling to underpayment of skilled workers) and $\mathrm{Wu}$ and Xie (2003) investigated the differences in educational returns across market and state enterprises. Heckman and $\mathrm{Li}$ (2004) showed the importance of considering heterogeneity and selection bias in the econometric estimation of return to college education in China. More recently, Li et al (2005) tested the causal effect of education on earnings and the consequences of omitted variable bias using the data on twins, and Zhang et al (2005) examined how economic returns to schooling in urban China changed over time (from 1988 to 2001). 
In contrast to the above, we focus on identifying the existence and scale of divergences or imbalances across educational levels in China. This issue is extremely important. Heckman (2003) recently showed that economic performance could be enhanced by equalizing returns across all types (and levels) of investments. In China, however, the level of investment across educational levels may not necessarily be proportional. For example, if the private returns to undergraduate level are relatively low because students have to pay relatively more on tuition and boarding as well as forgo their income by pursuing their university degrees, students could be discouraged from investing in higher education. This could give rise to more acute shortages in skilled labor at the time when the country's economy continued to boom. In addition, we also examine how social and private returns change over time. An implication is if the social return to a particular education level were rising over time while the returns to the other education levels were declining, then the investment or subsidy amounts were not proportional or balanced. In this paper, we aim to detect any such divergence and suggest ways to correct the problems.

\section{The Data}

Our cost and benefit data are available for the period 1998-2001 and for different educational levels: junior secondary, senior secondary, junior college, undergraduate and postgraduate (Masters and $\mathrm{PhD}$ ). There are cases when the matching data sets are not available. For example, private costs on undergraduate and postgraduate education are available but government costs on these two disaggregate sectors are not available. Only the government costs on higher education as a whole are available. Our costs data were obtained from China Statistical Year Books and benefit (wage) data from Chinese Labor Statistical Yearbook, various issues.

The private education cost data (itemized according to school fee, boarding etc.) are summarized in Table 1 . The total costs of secondary education in China were seen to be much lower than that of higher education. The social costs of investment in education include the private and government costs. These are tabulated in Table 2. Private costs, as tabulated in Table 2, include all the items stated in Table 1 plus the private opportunity cost, which refers to the forgone salary that would have accrued during the period of study, had he or she remained in employment for the period concerned. The government cum social education outlays includes the recurrent grant and the capital grant released annually to subsidize the costs of education. Capital grant is provided for the existing construction projects while recurrent grant is the major annual cost of running the institutions. Since the number of student enrolling in different education level vary, the costs data are converted to per student basis.

We use the wage data to estimate the economic benefits from the investments in education and these are shown in Table 3. The benefits from the investments in a particular level of education correspond to the wage hike accruing to individuals from further schooling. The wage increments can be derived accordingly. For instance, to pursue an undergraduate degree, the student would have to forgo 11,215 Yuan per year for about 4 years but he or she can obtain a higher wage of 17,774 Yuan per year over his or her entire working life. In this case, the wage increment is $(17,774-11,215)$ Yuan per year. We also used other data such as government bond rates, average number of years for undergraduate education, etc. The sources of these data are provided, where relevant, in the footnotes of Tables 1-4.

\section{Analysis of IRR: The Model and Results}

The general cost and benefit framework is expressed as:

$$
\sum_{t=0}^{n} \frac{B_{t}-C_{t}}{(1+r)^{t}}=0
$$

where $B_{t}$ is benefit in year $t, C_{t}$ is cost incurred in year $t, r$ is internal rate of return to the investment, and $n$ is individual earning life span (assumed to terminate at the age of 60 in China) when the same cohort of the graduates retires from the workforce. Our internal rates of return estimates were found to be sensitive to the number of years estimated for each educational level. In our empirical analysis, the junior and senior secondary education lasts for six years whereas the undergraduate and postgraduate levels were estimated to last for 4.3 and 3.8 years, respectively (the estimation procedures are available upon request). Our IRR results, computed using the wage increment approach, are presented in Table 4.

Table 4 shows that the social internal rates of returns are higher than the social opportunity costs of capital (represented by the long-term government bond rates), pointing to the importance of such investments. Our estimates are consisted with Heckman (2003) and Zhang (2005), which showed that the economic returns to higher education were rising over time. The social rates of return to higher education investments in China were found to be lower than the returns to the secondary level, consistent with previous finding, which showed that the educational returns were lowest at the highest level. It is of interest that, over time, the returns to higher 
education were increasing whilst the returns to secondary level were declining. The increasing social return to higher education was attributed to the fact that graduates' wages rose faster than the total costs over time. The increases in wages could be due to undersupply of graduate/skilled workers as the Chinese economy boomed. At the same time, there could be oversupply of secondary school leavers. The Chinese Government could therefore correct such an imbalance by investing proportionally more in higher vis-à-vis secondary education.

The social internal rates of returns were found, level by level, to be smaller than the private IRR (see Table 4). This is because the government costs of subsidy were excluded from our estimates of private IRR whereas the wage benefits for both social and private IRR estimations were essentially the same. Again, the private internal rates of returns were in all cases larger than the long-term opportunity costs of capital. A surprising result emanating from Table 4 is that the private internal rates of returns to undergraduate education were much lower than the returns to the secondary and postgraduate levels. In the absence of government costs, this simply means that secondary school leavers may under-enroll in undergraduate courses, especially during the earlier period when the divergence in returns were more acute. This could have given rise to the undersupply of skilled workers starting from the earlier years and the problem had persisted as we observed in recent years that the skilled labor shortages in China had deteriorated. This problem could be ameliorated via government subsidies or assistance to encourage secondary leavers to enroll in university courses.

It is of interest that the rates of return to education in China were found to be higher at the postgraduate than at the undergraduate level. This is in contrast to the previous findings (reported for countries other than China), which showed that the highest level registered the lowest return. The result implies that undergraduate students were more willing to enroll in postgraduate courses than secondary school leavers in undergraduate courses.

Another form of divergence is when social IRR is larger/smaller than private IRR. In this case, government can correct this type of "market failure" by raising/reducing its level of investment. Table 4 shows that, in the case of secondary education, the social returns were significantly smaller than the private returns. This could have given rise to over-investments in the secondary level of China's education system. In the case of higher education, the social returns were also smaller than the private returns. However, given that the positive external benefits associated with higher education spin-off (e.g. additional GDP growth, as in Voon 2001 and Cook 2004) were not estimated, the social IRR to university education in China could well be underestimated. Hence, we cannot reasonably deduce at this point that China over-invested in higher education.

\section{Concluding Comments}

Our simple analysis of IRR in this paper points to several imbalances or divergences in China's education sector. Such imbalances were more serious in the past than in recent years, judging from the degree of the divergence over time. Notwithstanding this, the problems have persisted as China still encounters the problems with undersupply of graduates or skilled workers and over-supply of unskilled labor. This is caused, inter alia, by the relative lack of incentives for secondary school leavers to enroll in undergraduate education as well as the relative under-investment by The Government in higher education. It is imperative for China to rectify these imbalances so that more qualified workers could be produced to meet the surging demand for skilled labor associated with the booming economy.

A merit of this paper is that we apply actual primary data to a simple empirical model. Hence, a direct reliable comparison of results is facilitated without resorting to derived data or models and robust results and conclusions could be derived. However, the interpretation of results and policy outcome may be limited by (a) the lack of empirical data on recent years (2002 to present) and (b) the absence of calculation of the external spillover effects of China's investments accruable from higher education. Further research to extend the above is therefore warranted.

\section{References}

Acemoglu, D. (1996). A Microfoundation for Social Increasing Returns in Human Capital Accumulation. Quarterly Journal of Economics, 111 (3), 639-953. http://dx.doi.org/10.2307/2946672

Ashenfelter, O. \& Krueger, A. (1994). Estimates of the Economic Returns to Schooling from a New Sample of Twins. American Economic Review, 84 (5), 1157-73.

Brown, P. \& Park, A. (2002). Education and Poverty in Rural China. Economics of Education Review, 21, 523-541. http://dx.doi.org/10.1016/S0272-7757(01)00040-1

Cook, D. (2004). Experience and Growth. Economics Letters, 85, 53-56. http://dx.doi.org/10.1016/j.econlet.2004.03.020 
Fleisher, B.M. \& Wang, X. (2004). Skill Differentials, Return to Schooling, and Market Segmentation in a Transition Economy: The Case of Mainland China. Journal of Development Economics, 73, 315-328. http://dx.doi.org/10.1016/j.jdeveco.2002.12.002

Gustafsson, B. \& Li, S. (2000). Economic Transformation and the Gender Earnings Gap in Urban China. Journal of Population Economics, 13, 305-329. http://dx.doi.org/10.1007/s001480050140

Heckman, J.J. (2003). China's Investment in Human Capital. Economic Development and Cultural Change, 51 (4), 795-804. http://dx.doi.org/10.1086/378050

Heckman, J.J. \& Li. X. (2004). Selection Bias, Comparative Advantage and Heterogeneous Returns to Education: Evidence from China in 2000. Pacific Economic Review, 9 (3), 155-171. http://dx.doi.org/10.1111/j.1468-0106.2004.00242.x

Hertz, T. (2003). Upward Bias in the Estimated Returns to Education: Evidence from South Africa. The American Economic Review, 93 (4), 1354-1368. http://dx.doi.org/10.1257/000282803769206331

Johnson, E.N. \& Chow, G.C. (1997). Rates of Return to Schooling in China. Pacific_Economic Review, 2 (2), 101-113. http://dx.doi.org/10.1111/1468-0106.t01-1-00026

Li, H. (2003). Economic Transition and Returns to Education in China. Economics of Education Review, 22, 317-328. http://dx.doi.org/10.1016/S0272-7757(02)00056-0

Li, H., Liu, P.W., Ma, N. \& Zhang, J. (2005). Does Education Pay in Urban China? Estimating Returns to Education Using Twins. Chinese University of Hong Kong Research Papers, 1-37.

Polachek, S.W. \& Siebert, W.S. (1993). The economics of earnings. The Cambridge University: London. http://dx.doi.org/10.1017/CBO9780511522062

Psacharapoulos, G. (1994). Returns to Investment in Education: A Global Update. World_Development, 22 (9), 1325-1343. http://dx.doi.org/10.1016/0305-750X(94)90007-8

Voon, J.P. (2001). Measuring Social Returns to Higher Education Investments in Hong Kong: Production Function Approach. Economic of Education Review, 20, 503-510. http://dx.doi.org/10.1016/S0272-7757(00)00021-2

$\mathrm{Wu}, \mathrm{X} . \&$ Xie, Y. (2003). Does the Market Payoff? Earnings Returns to Education in China. American Sociological Review, 68 (3), 425. http://dx.doi.org/10.2307/1519731

Zhang, J., Zhao, Y., Park, A. \& Song X. (2005). Economic Returns to Schooling in Urban China, 1988 to 2001. Journal of Comparative Economics, 33, 730-752. http://dx.doi.org/10.1016/j.jce.2005.05.008

Zhao, Y. (2001). Earnings Differentials between State and Non-state Enterprises in Urban China. Beijing University Research Paper, 1-25. 
Table 1. Private Costs (Yuan/student/year) of Education in China

\begin{tabular}{|c|c|c|c|c|c|c|c|c|}
\hline & School Fee & Insur ance & Boarding & Registration & Books & Health & Others & Total \\
\hline \multicolumn{9}{|l|}{1998} \\
\hline Postgraduate & 6634 & 398 & 7961 & 119 & 700 & 0 & 0 & 15813 \\
\hline Undergraduate & 3317 & 398 & 7961 & 119 & 600 & 0 & 0 & 12396 \\
\hline Secondary & 228 & 0 & 239 & 0 & 171 & 40 & 223 & 901 \\
\hline \multicolumn{9}{|l|}{1999} \\
\hline Postgraduate & 6983 & 419 & 8380 & 126 & 735 & 0 & 0 & 16643 \\
\hline Undergraduate & 3492 & 419 & 8380 & 126 & 630 & 0 & 0 & 13046 \\
\hline Secondary & 279 & 0 & 251 & 0 & 181 & 40 & 235 & 986 \\
\hline \multicolumn{9}{|l|}{2000} \\
\hline Postgraduate & 7351 & 441 & 8821 & 132 & 772 & 0 & 0 & 17517 \\
\hline Undergraduate & 3675 & 441 & 8821 & 132 & 662 & 0 & 0 & 13731 \\
\hline Secondary & 369 & 0 & 265 & 0 & 190 & 40 & 247 & 1111 \\
\hline \multicolumn{9}{|l|}{2001} \\
\hline Postgraduate & 7738 & 464 & 9285 & 139 & 810 & 0 & 0 & 18437 \\
\hline Undergraduate & 3869 & 464 & 9285 & 139 & 695 & 0 & 0 & 14452 \\
\hline Secondary & 459 & 0 & 279 & 0 & 200 & 40 & 260 & 1238 \\
\hline
\end{tabular}

Table 2. Social Costs of Education in China

$\begin{array}{cccccccc}\text { Central Gov't } & \text { Public } & \text { Public } & \text { Other Public } & \text { Total } & \text { Gov't Cost } & \text { Private Cost } & \text { Social Cost } \\ \text { Allocation } & \text { Organizations } & \text { Donations } & \text { Sources } & & \text { per student } & \text { per student } & \text { per student }\end{array}$

\begin{tabular}{|c|c|c|c|c|c|c|c|c|}
\hline \multirow{2}{*}{$\begin{array}{l}1998 \\
\text { Higher Education }\end{array}$} & \multicolumn{4}{|c|}{$(10,000$ yuan $)$} & \multicolumn{4}{|c|}{ (yuan) } \\
\hline & 3837813 & 23854 & 118194 & 1146689 & 5126550 & 15038 & 18257 & 33296 \\
\hline Senior Secondary & 777719 & 62304 & 115417 & 238142 & 1193582 & 1272 & 1346 & 2619 \\
\hline Junior Secondary & 10769804 & 252655 & 942722 & 950503 & 12915684 & 669 & n/a & $\mathrm{n} / \mathrm{a}$ \\
\hline \multicolumn{9}{|l|}{1999} \\
\hline Higher Education & 4728312 & 39083 & 163891 & 1336334 & 6267619 & 15161 & 19215 & 34376 \\
\hline Senior Secondary & 866170 & 67775 & 130723 & 278118 & 1342784 & 1279 & 1413 & 2692 \\
\hline Junior Secondary & 11836799 & 310017 & 701454 & 1131554 & 13979824 & 725 & $\mathrm{n} / \mathrm{a}$ & $\mathrm{n} / \mathrm{a}$ \\
\hline \multicolumn{9}{|l|}{2000} \\
\hline Higher Education & 5637055 & 90904 & 153444 & 1783025 & 7664428 & 13783 & 20222 & 34005 \\
\hline Senior Secondary & 1067895 & 106717 & 152680 & 330467 & 1657758 & 1380 & 1483 & 2863 \\
\hline Junior Secondary & 13085667 & 381715 & 593832 & 1270306 & 15331520 & 799 & $\mathrm{n} / \mathrm{a}$ & $\mathrm{n} / \mathrm{a}$ \\
\hline \multicolumn{9}{|l|}{2001} \\
\hline Higher Education & 6659987 & 253802 & 174308 & 2263089 & 9351185 & 13005 & 21283 & 34287 \\
\hline Senior Secondary & 1335336 & 128137 & 150976 & 452305 & 2066753 & 1471 & 1557 & 3028 \\
\hline Junior Secondary & 15807992 & 498030 & 557738 & 1431877 & 18295636 & 964 & $\mathrm{n} / \mathrm{a}$ & $\mathrm{n} / \mathrm{a}$ \\
\hline
\end{tabular}

Source: China Statistical Yearbooks, various issues.

Note: Private cost per student excludes tuition fee, which is transfer payment. 
Table 3. Average Salary (Yuan/Year) for Various Education Levels in China

\begin{tabular}{lrrrr}
\hline & $\mathbf{1 9 9 8}$ & $\mathbf{1 9 9 9}$ & $\mathbf{2 0 0 0}$ & $\mathbf{2 0 0 1}$ \\
\hline Doctorate & 15761 & 19563 & 20196 & 27973 \\
Masters & 22547 & 29736 & 27552 & 37047 \\
Postgraduate average & 19154 & 24650 & 23874 & 32510 \\
Senior College & 14610 & 17123 & 16443 & 20662 \\
& & & & \\
Junior College & 11702 & 13676 & 12459 & 14887 \\
Undergraduate average & 13156 & 15400 & 14451 & 17775 \\
& & & & \\
Senior Secondary & 9676 & 10916 & 9806 & 11215 \\
& & & & \\
Junior Secondary & 8593 & 9554 & 8966 & 10046 \\
Secondary Average & 9135 & 10235 & 9386 & 10631 \\
\hline
\end{tabular}

Source: Chinese Labor Statistics Yearbook, various issues

Table 4. Internal Rates of Returns to Education in China

\begin{tabular}{|c|c|c|c|c|}
\hline Social IRR & \multicolumn{2}{|c|}{ Higher Education } & Secondary & LTGBR \\
\hline 1998 & \multicolumn{2}{|c|}{$9 \%$} & $18 \%$ & $5.5 \%$ \\
\hline 1999 & \multicolumn{2}{|c|}{$10 \%$} & $20 \%$ & $4.7 \%$ \\
\hline 2000 & \multicolumn{2}{|c|}{$10 \%$} & $15 \%$ & $2.9 \%$ \\
\hline 2001 & \multicolumn{2}{|c|}{$13 \%$} & $17 \%$ & $2.8 \%$ \\
\hline Private IRR & Postgraduate & Undergraduate & Secondary & LTGBR \\
\hline 1998 & $14 \%$ & $10 \%$ & $25 \%$ & $5.5 \%$ \\
\hline 1999 & $18 \%$ & $12 \%$ & $28 \%$ & $4.7 \%$ \\
\hline 2000 & $18 \%$ & $12 \%$ & $18 \%$ & $2.9 \%$ \\
\hline 2001 & $24 \%$ & $14 \%$ & $22 \%$ & $2.8 \%$ \\
\hline
\end{tabular}

Source: http://www.chinabond.com.cn

Note: LTGBR denotes long-term (10 years) government bond rate. 